\title{
THE ECONOMIC EFFICIENCY OF THE FERTILIZERS APPLICATION UNDER AGRICULTURAL CROPS FOR DIFFERENT SOIL TILLAGE
}

\author{
A. BYKIN, Doctor of Agricultural Sciences, Professor, \\ Corresponding-Member of the NAAS \\ N. BYKINA, PhD, Associate Professor \\ N. BORDYUZHA, PhD, Associate Professor \\ National University of Life and Environmental Sciences of Ukraine \\ A. IVANYTSKA, Senior Researcher, \\ Ukrainian Institute for Plant Variety Examination \\ E-mail:bykin090863@gmail.com,bykinanina@ukr.net,nadia_bordyuzha@ukr.net
}

\begin{abstract}
In the Ukrainian economic conditions there is a competition between producers of the crops products and it caused their competitiveness in national and international markets. This causes increasing of the farm efficiency. One of the ways for increasing of the farm efficiency is minimization of the soil tillage and rational use of fertilizers. So, the rational fertilizers application for different soil tillage was researched. There were ploughing and mini-till and no-till and split formation. The effect of the ammonium nitrate application and UAN solution on background of the phosphatepotassium fertilizers were researched for these types of soil tillage. These factors were researched for next crops: corn, soybean and spring wheat. For corn the rate of mineral fertilizers was N140P100K100, for soybean it was N60P60K60, for spring wheat it was N100P80K80. Results indicate that the optimal soil tillage for all crops was split formation. And better nitrogen fertilizers were urea-ammonium nitrate solution for two crops (soybean, spring wheat) because in these variants was maximal profitability in these crop production system. It was $95.0 \%$ for soybean and $58.1 \%$ for spring wheat. For corn the best fertilizers were ammonium nitrate where was maximal profitability (54.7\%).

Keywords: ammonium nitrate (Naa), urea-ammonium nitrate solution (UAN), soil tillage, agricultural crops.
\end{abstract}

\section{Introduction.}

The modern economic challenges in Ukraine's agriculture are unreasonably impulse producers to search energy-saving crop production system. Unstable pricesfor the crop production andcon- stant price increasing for technological resources cause change same elements of the crop production systems and theirs whole. A reserve in this direction can be only a transition to new principles of cultivation, which provides a positive economic effect on the background of the 
use of scientific and practical achievements (new varieties and hybrids, technologies, high-efficiency fertilizers, plant protection products, etc.). However, the introduction of such technologies should have a positive effect on the soil fertility and nutrition conditions for crops, and, consequently, on the growth and development of plants.

\section{The research and publication analysis.}

For many years, mechanical soil cultivation has been at the center of the scientific debate. The main part of the cost of resources and energy in the production of crop products take place for it implementation. Significant environmental losses and economic losses lead to the need for optimization and adaptation of land management [1].

In the agriculture of the countries in the world (Canada, USA, Argentina, China) there is a transition from anthropogenic, resource-intensive and destructive methods of soil tillage for ecosystems to soil protection, adaptive soil tillage systems. These new systems are characterized by a partial or complete abandonment of the plowing and lack of vertical mixing of the arable layer and minimal violation of the soil cover by agricultural machines and compulsory mulching, that is, the use of plant residuesfor protectionof the upper fertile layer from the detrimental effects of the energy of water and wind, and saving of the soil moisture from unproductive evaporation[2]. Traditional soil tillage systems do not always meet the current ecological and economic requirements.

Minimizing soil cultivation, in this aspect, is an approach that requires longtime action and significant changes in traditions. On the one hand, its wide im- plementation is possible.And on the other hand, a certain agronomic, ecological and socio-economic basis is needed. This is especially true for new knowledge about the processes, occurring in soils, and plants for implementing the above-mentioned technologies. At first glance, it seems that the reduction of technological processes in the soil tillage system results a direct saving of resources.But it may not always be a reason for lowering the cost of production and obtaining a cost-effective result. After all, the changes in soil cultivation and fertilizer system affect directly the environment that is the basis of plant growth and development. Not always such a way provides an optimization of such conditions. Therefore, the transition to conservative soil practices must necessarily be grounded.

From an economic point of view, the use of no-till can be unprofitable in the first years of implementation. At first glance, this method is limited to 3-4 processes: fertilizer application and pesticides application, sowing and harvesting. But the analysis of typical operating crop production system shows that it is necessary to apply an increased amount of herbicides and increasedof the rate of nitrogen fertilizersby $10-20 \%$ [3].

For switch to no-till, it is necessary to disposable large amounts of money for a direct sowing seed drill. Its mass (200$300 \mathrm{~kg}$ on a disk knife) and working bodies can provide high-quality seeding of seed in arable-free soils. The price of different sowing machines with different trapping widths and a set ranges from 30,000 to $300,000 \$$, which can become a serious problem for farms in Ukraine. However, the use of only one seed drill contributes to an increase of the production over the whole complex of works for 1 hour from 2.4 ha for plowing up to 14 ha for no-till in average [4]. 
The no-till gives some economic benefits in the early years. They relate, first of all, to reducing the cost of fuel and lubricants, human labor and depreciation of machinery and tractor park [5]. The analysis of economic efficiency of production of crop products for notill showed that the technical load is reduced by 2.4 times, and fuel consumption is decreased by 2 times, man-year is decreased by 2.3 times. According to $\mathrm{G}$. Sini et al. [4] the deepening of soil cultivating machines by $1 \mathrm{~cm}$ increases fuel consumption by an average of 1 l/ha.

Getting higher returns for no-till provides less yield than plowing. According to calculations N. Şapre et al. [6] this indicator for traditional corn growing technology should be $7.0 \mathrm{t} / \mathrm{ha}$ $(+20 \$)$ and for no-till should be enough $4.0 \mathrm{t} / \mathrm{ha}(+390$ \$).

To obtain high economic performance, long-term usage of no-till is necessary [7]. During the 10-year period, the number of weeds is gradually decreasing, biological protection from pests and diseases is increasing, and the layer of plant resides is grown. In particular, in LLC "Agromir" the yield of corn was $9.0 \mathrm{t} / \mathrm{ha}$. Significantly lower costs of cultivation. The level of profitability reached $115 \%$ [8].

Thus, no-till has energy and economic benefits already in the first years of cultivation. This is due to the refusal of the energy and cost-effective technological processes such as plowing. Lack of soil cultivation causes reduction of soil losses from erosion. But, there is a need for additional application of nitrogen fertilizers and plant protection products. So, the question of optimizing the supply conditions for minimizing soil tillage is relevant.

The main goal for complex investigationisto research the influence of different systems of soil tillage and fertilizers appli- cation economic efficiency for short crop rotation with the following alternating crops: spring wheat; corn; soybean

\section{Material and Methods.}

The field trials were located in LLC "Biotech LTD" in Forest-Steppe in Ukraine and were made between 20012 and 2014 by Department of Agrochemistry and the quality of crop products NULES.The field trials included four variants of soil tillage and two variants of fertilizer application. The soil tillage was plowing, mini-till, no-till and split formation. The recommended fertilizers rates were applied under crops. The two forms of the nitrogen fertilizers were researched: solid (ammonium nitrate) and liquid (urea-ammonium nitrate solution (UAN)). The field trials are located on the dark-grey podzolic soil.

Hybrid corn Emily F1 (Originator KWS, Germany) was sown with a seed rate of 80,000 seeds / ha.Variety spring wheat Ziomoyarka was sown in rate 20 $\mathrm{kg} / \mathrm{ha}$ and variety soybean Merlin was sown in rate $90 \mathrm{~kg} / \mathrm{ha}$. The sowing area was $70 \mathrm{~m}^{2}$ and accounting was made from $60 \mathrm{~m}^{2}$. The arrangement of the research plots was systematic in tree replication. The crop harvesting was made in every variant apart. The mathematic estimation of research results was made by dispersion analysis.

\section{Results and Discussions.}

In economic conditions in Ukraine there is increased competition between the foreign producers of the crop products and national producers on the Ukrainian and international markets. It is need increasing of the economic farm effectiveness. In the side, the agricultural producers have limited resource po- 


\section{The economic efficiency of the fertilizers application for different types of soil tillage for corn $\left(\right.$ Emilio $\left.F_{1}\right)$}

\begin{tabular}{|c|c|c|c|c|c|c|}
\hline $\begin{array}{l}\text { Crops fertilizers } \\
\text { system }\end{array}$ & $\begin{array}{c}\text { Crop } \\
\text { yield, } \mathrm{t} / \mathrm{ha}\end{array}$ & $\begin{array}{l}\text { Crop yield } \\
\text { price, \$/ha }\end{array}$ & $\begin{array}{l}\text { Producer } \\
\text { costs, \$/ha }\end{array}$ & $\begin{array}{c}\text { Reve- } \\
\text { nue, } \$ / \text { ha }\end{array}$ & $\begin{array}{l}\text { Profitabil- } \\
\text { ity, } \%\end{array}$ & $\begin{array}{c}\text { Payback, } \\
\$ / \$\end{array}$ \\
\hline \multicolumn{7}{|c|}{ plowing $(25-27 \mathrm{~cm})$} \\
\hline $\mathrm{N}_{140} \mathrm{P}_{100} \mathrm{~K}_{100}(\mathrm{AN})$ & 10.4 & 589.33 & 411.31 & 178.02 & 43.3 & 0.43 \\
\hline $\mathrm{N}_{140} \mathrm{P}_{100} \mathrm{~K}_{100}(\mathrm{UAN})$ & 10.4 & 589.33 & 404.58 & 184.76 & 45.7 & 0.46 \\
\hline \multicolumn{7}{|c|}{ mini-till $(12-14 \mathrm{~cm})$} \\
\hline $\mathrm{N}_{140} \mathrm{P}_{100} \mathrm{~K}_{100}(\mathrm{AN})$ & 9.92 & 562.13 & 408.79 & 153.55 & 37.6 & 0.38 \\
\hline $\mathrm{N}_{140} \mathrm{P}_{100} \mathrm{~K}_{100}(\mathrm{UAN})$ & 9.73 & 551.37 & 391.42 & 159.95 & 40.9 & 0.41 \\
\hline \multicolumn{7}{|c|}{ no-till } \\
\hline $\mathrm{N}_{140} \mathrm{P}_{100} \mathrm{~K}_{100}(\mathrm{AN})$ & 10.4 & 589.33 & 403.62 & 185.71 & 46.0 & 0.46 \\
\hline $\mathrm{N}_{140} \mathrm{P}_{100} \mathrm{~K}_{100}(\mathrm{UAN})$ & 9.96 & 564.40 & 394.61 & 169.79 & 43.0 & 0.43 \\
\hline \multicolumn{7}{|c|}{ split formation $(38-\mathrm{cm})$} \\
\hline $\mathrm{N}_{140} \mathrm{P}_{100} \mathrm{~K}_{100}(\mathrm{AN})$ & 11.3 & 640.33 & 416.63 & 223.71 & 54.7 & 0.55 \\
\hline $\mathrm{N}_{140} \mathrm{P}_{100} \mathrm{~K}_{100}(\mathrm{UAN})$ & 10.2 & 578.00 & 409.81 & 168.19 & 41.0 & 0.41 \\
\hline
\end{tabular}

tential and every day the prices of the basic compounds of the crop production systems are increased. So, minimization of the soil tillage and selection of the rational forms of the mineral fertilizers are one of the optimal ways for improvement of the economic efficiency of the plant growing. Soil no-till, such as soil tillage, provides maximal decreasing of the physical influence on soil. But, for it positive effect on the soil fertility there is long period.

In our researches there is determined that producer costs for corn growing were decreased in the conditions of the minimizing of soil tillage (table 1). This index was decreased by 4.73-7.67 $\$$ / ha in comparative to plowing and mini-till when ammonium nitrate was applied and by 9.97-11.1 $\$ /$ ha in variant with UAN application. It should be note, corn is high cost crop and for seeds price in 2012-2014.The level of the profitability did not increase more than $54.7 \%$, but it was not less $37.6 \%$. The maximal index was gotten for soil split formation with
AN application and minimal index was for mini-till with this fertilizer.

Payback of the producer costs in conditions of the no-till was similar to index for plowing regardless from forms of nitrogen fertilizers. It was less for soil mini-till.

So, for implementation of the resource-save soil tillage, the economic parameters, that are characterized the farm revenue, were similar or more in comparative to plowing and producers' costs was less.

The indexes of economic efficiency of the soybean growing on dark-grey podzolic soil depended from forms of the nitrogen fertilizers application and types of soil tillage. Producers costs for soybean growing is decreased in conditions of the mini-till (297.46 \$/ ha) in variant with AN application (table 2). It was 298.40 $\$ /$ ha in variant with UAN application. The no-till caused decreased the producers' costs even more. They were 289.67 $\$ /$ ha for AN application and 285.92 $\$ /$ ha for UAN solution application. 


\section{The economic efficiency of the fertilizers application for different types of soil tillage for soybean $\left(\right.$ Merlin $\left.F_{1}\right)$}

\begin{tabular}{|c|c|c|c|c|c|c|}
\hline $\begin{array}{l}\text { Crops fertilizers } \\
\text { system }\end{array}$ & $\begin{array}{c}\text { Crop yield, } \\
\text { tha }\end{array}$ & $\begin{array}{l}\text { Crop yield } \\
\text { price, \$/ha }\end{array}$ & $\begin{array}{l}\text { Producer } \\
\text { costs, \$/ha }\end{array}$ & $\begin{array}{c}\text { Revenue, } \\
\$ / \text { ha }\end{array}$ & $\begin{array}{l}\text { Profitabili- } \\
\text { ty, } \%\end{array}$ & $\begin{array}{c}\text { Payback, } \\
\$ / \$\end{array}$ \\
\hline \multicolumn{7}{|c|}{ plowing $(25-27 \mathrm{~cm})$} \\
\hline $\mathrm{N}_{60} \mathrm{P}_{60} \mathrm{~K}_{60}(\mathrm{AN})$ & 3.87 & 554.21 & 301.67 & 252.54 & 83.7 & 0.84 \\
\hline $\mathrm{N}_{60} \mathrm{P}_{60} \mathrm{~K}_{60}(\mathrm{UAN})$ & 4.31 & 598.66 & 297.86 & 300.80 & 101 & 1.01 \\
\hline \multicolumn{7}{|c|}{ mini-till $(12-14 \mathrm{~cm})$} \\
\hline $\mathrm{N}_{60} \mathrm{P}_{60} \mathrm{~K}_{60}(\mathrm{AN})$ & 3.60 & 500.04 & 297.46 & 202.58 & 68.1 & 0.68 \\
\hline $\mathrm{N}_{60} \mathrm{P}_{60} \mathrm{~K}_{60}(\mathrm{UAN})$ & 3.61 & 501.43 & 298.40 & 203.03 & 68.0 & 0.68 \\
\hline \multicolumn{7}{|l|}{ no-till } \\
\hline $\mathrm{N}_{60} \mathrm{P}_{60} \mathrm{~K}_{60}(\mathrm{AN})$ & 2.82 & 391.70 & 289.67 & 102.03 & 35.2 & 0.35 \\
\hline $\mathrm{N}_{60} \mathrm{P}_{60} \mathrm{~K}_{60}(\mathrm{UAN})$ & 3.32 & 461.15 & 285.92 & 175.23 & 61.3 & 0.61 \\
\hline \multicolumn{7}{|c|}{ split formation $(38-\mathrm{cm})$} \\
\hline $\mathrm{N}_{60} \mathrm{P}_{60} \mathrm{~K}_{60}(\mathrm{AN})$ & 4.21 & 584.77 & 305.85 & 278.92 & 91.2 & 0.91 \\
\hline $\mathrm{N}_{60} \mathrm{P}_{60} \mathrm{~K}_{60}(\mathrm{UAN})$ & 4.29 & 595.88 & 305.56 & 290.32 & 95.0 & 0.95 \\
\hline
\end{tabular}

The minimization of soil tillage and soil no-till caused changes of the soil physical properties. The soil density was increased and it is caused negative effect on soybean productivity. So, the seeds yield and yield cost were less. And it decreased the level of profitability of the soybean growing. It was $68.1 \%$ in variant with AN application and 35.2\% for no-till in variant with UAN application.

The producers' costs were increased to $301.67 \$ /$ ha in conditions of the soil plowing and AN application and to $305.85 \$ /$ ha in conditions of the soil split formation for fertilizers application of the ammonium nitrate. But, in these variants were better seeds yield and it caused high level of the profitability. Using of the UAN for these variants of the soil tillage caused profitability $101 \%$ (plowing) and 91.2\% (split formation).

The minimization of the soil tillage for spring wheat caused effective using of the resources and of the producers' costs. For minimization of soil tillage, seeds yield costs increased and was
234.62-268.84 \$/ ha (table 3). It was caused by seeds yield level in these variants. The AN application caused increasing of the seed yield cost in comparative to UAN application for all types of soil tillage.

The costs of the soil tillage are grave in the producers' costs. In conditions of our field trials no-till caused minimal producers costs for spring wheat growing (163.40-169.59 \$/ha). And there were maximal producers' costs for plowing (187.46-201.33 \$/ ha). For soil mini-till the producers' costs increased in comparative to no-till and were 171.37-177.65 $\$ /$ ha. This index for soil split formation was more too. It was 173.13-190.48 \$ / ha.

The UAN application caused less producers costs in comparative to ammonium nitrate. It is caused by fertilizers price and specific of its application. The producers' costs in variant with UAN application were 163.40-187.45 $\$ /$ ha for different types of soil tillage. And invariant with AN application it's were 169.59-201.33 \$ / ha. 


\section{The economic efficiency of the fertilizers application for different types of soil tillage for spring wheat (Zymoiarka)}

\begin{tabular}{|c|c|c|c|c|c|c|}
\hline $\begin{array}{l}\text { Crops fertilizers } \\
\text { system }\end{array}$ & $\begin{array}{c}\text { Crop } \\
\text { yield, } t / h a\end{array}$ & $\begin{array}{l}\text { Crop yield } \\
\text { price, } \$ / \text { ha }\end{array}$ & $\begin{array}{c}\text { Producer } \\
\text { costs, } \$ / \text { ha }\end{array}$ & $\begin{array}{l}\text { Revenue, } \\
\$ / \text { ha }\end{array}$ & $\begin{array}{l}\text { Profitabili- } \\
\text { ty, } \%\end{array}$ & $\begin{array}{l}\text { Payback, } \\
\$ / \$\end{array}$ \\
\hline \multicolumn{7}{|c|}{ plowing $(25-27 \mathrm{~cm})$} \\
\hline $\mathrm{N}_{100} \mathrm{P}_{80} \mathrm{~K}_{80}(\mathrm{AN})$ & 3.61 & 220.57 & 201.33 & 19.24 & 9.56 & 0.10 \\
\hline $\mathrm{N}_{100} \mathrm{P}_{80} \mathrm{~K}_{80}(\mathrm{UAN})$ & 3.95 & 241.35 & 187.46 & 53.88 & 28.7 & 0.29 \\
\hline \multicolumn{7}{|l|}{ mini-till $(12-14 \mathrm{~cm})$} \\
\hline $\mathrm{N}_{100} \mathrm{P}_{80} \mathrm{~K}_{80}(\mathrm{AN})$ & 3.84 & 234.62 & 177.65 & 56.97 & 32.1 & 0.32 \\
\hline $\mathrm{N}_{100} \mathrm{P}_{80} \mathrm{~K}_{80}(\mathrm{UAN})$ & 4.40 & 268.84 & 171.37 & 97.47 & 56.9 & 0.57 \\
\hline \multicolumn{7}{|l|}{ no-till } \\
\hline $\mathrm{N}_{100} \mathrm{P}_{80} \mathrm{~K}_{80}(\mathrm{AN})$ & 3.4 & 240.73 & 169.59 & 71.15 & 42.0 & 0.42 \\
\hline $\mathrm{N}_{100} \mathrm{P}_{80} \mathrm{~K}_{80}$ (UAN) & 4.14 & 252.34 & 163.40 & 88.94 & 54.4 & 0.54 \\
\hline \multicolumn{7}{|c|}{ split formation $(38-\mathrm{cm})$} \\
\hline $\mathrm{N}_{100} \mathrm{P}_{80} \mathrm{~K}_{80}(\mathrm{AN})$ & 4.50 & 274.95 & 190.48 & 84.47 & 44.3 & 0.44 \\
\hline $\mathrm{N}_{100} \mathrm{P}_{80} \mathrm{~K}_{80}(\mathrm{UAN})$ & 4.48 & 273.73 & 173.13 & 100.59 & 58.1 & 0.58 \\
\hline
\end{tabular}

The level of the producers' costs and seed yield price caused minimal revenue in conditions of the plowing of the darkgrey podzolic soil. It was 19.24-53.88 $\$$ / ha. For mini-till it was more by $1.8-3.0$ times in comparative to plowing (56.97$97.47 \$ /$ ha). For no-till revenue increased by 1.7-3.7 times in comparative to minitill. Maximal revenue was gotten in variant with soil split formation. It increased by 1.2 times to no-till and by 1.5 times to mini-till and by 1.9-4.4 times to plowing.

For UAN application revenue increased for all types of the soil tillage in comparative to AN application. It is caused decreasing of the producers costs on fertilizer application and fertilizers price. It was 53.88-100.59 \$ / ha.

Minimal profitability is caused by minitill. It was $9.56-28.7 \%$ with payback in 0.10 $0.29 \$ / \$$. For mini-till these indexes are increased to $32.9-56.9 \%$ and $0.32-0.57 \$ / \$$. No-till caused profitability to $42.0-54.4 \%$ and payback to $0.42-0.54 \$ / \$$. Maximal level of these indexes was gotten for soil split formation. It was $44.3-58.1 \%$ and $0.44-0.58 \$ / \$$.

\section{Conclusions.}

The using of the minimal soil tillage caused decreasing of the producers' costs for the crop production systems in crop rotation "corn-spring wheat-soybean" to soil plowing. The profitability for soybean growing and wheat growing was better in conditions of the soil split formation with UAN application. It was $95.0 \%$ and $58.1 \%$. But,the maximal profitability for spring wheat was 101 $\%$ when this crop had growing under plowing with UAN application. For corn growing there is not synonymous result. The maximal profitability was $54.7 \%$ for split formation and AN application.

So, these aspects will require future researches. And, since the UAN application in minimization of soil tillage provided decreasing of the producers' costs, it is necessary to further research the changes in soil properties and plant nutritional conditions in these soil tillage systems. 


\section{References}

1. Datsko, L. (2009). Degradaciya gruntiv problema siogodennya. [Soil degradation the problem todays]. Okhorona rodiuchosti gruntiv, 5, 75-78.

2. Shykula, M. K., Ridei, N. M., Maistrenko, V. H., Hlushchenko, O. Ye. (2003). Pokrashchennia ahrofizychnykh vlastyvostei hruntiv zastosuvanniam tekhnolohii biolohichnoho zemlerobstva. Biolohichni nauky I problem roslynnytstva. [The optimization of the agrophysical soil properties by biological farming. Biological sciences and plant growimg problems]. Zbirnyk naukovykh prats Umanskoho derzhavnoho ahrarnoho universytetu. 777-784.

3. Filipovic, D., Husnjak, S., Kosutic, S Gospodaric, Z. (2006). Effects of tillage systems on compaction and crop yield of AlbicLuvisol in Croatia. Journal of Terramechanics, 43 (2), 177-189.

4. Bondarenko, M. P., Sobko, M. H., Zubenok, O.V., etc. (2010). Zastosuvannia sposobiv osnovnoho obrobitku gruntu v sivozminakh [The using of the types for basic soil tillage in crop rotatios]. SAD, Ukraine, 24.
5. Derpsh, R. (2008). No-till dlia fermera (yz opыta, nakoplennoho $v$ Latynskoi Ameryke) [No-till for fermers (the practice geting in Letin America]. Zerno, 6, 20-27.

6. Șapre N., Pirnea I., Marin E.[et al.]. (2011). New results for maize crops cultivated in the no-tillagge system at the national institute for agricultural mechanization from Baneasa-Bucharest. Lucraristiintifice, 54, 211- 218.

7. Balaiev, A. D. (2010). Humusovanist gruntiv Pravoberezhnoho Lisostepu Ukrainy za riznykh umov yikh vykorystannia. [Humus reserve of the soils in Right-Bank Forest-Steppe of Ukraine for different conditions its' using]. Naukovyi visnyk Natsionalnoho universytetu bioresursiv I aryrodokorystuvannia Ukrainy («Ahronomiia»), 149, 357-362.

8. Lunkina, T. I. (2010). Efektyvnist intensyfkatsii vyrobnytstva silskohospodarskoi produktsi na osnovi no-till tekhnolohii. [The effect of the intensification for agricultural production based on no-till]. Visnyk ahrarnoi nauky Prychornomoria, 3, 118-123.

\section{А. Бикін, Н. Бикіна, Н. Бордюжа, А. Іваницька (2019). Економічна ефектив- ність застосування добрив під сільськогосподарські культури за різних способів обробітку грунту. PLANT AND SOIL SCIENCE, 10(1): 62-69. https://doi.org/10.31548/agr2019.02.062}

Анотація. В економічних умовах України $\epsilon$ конкуренція між виробниками продукції рослинництва, яка обумовлює їх конкурентноспроможність на внутрішньому і міжнародному ринках. Це забезпечує економічну ефективність господарств в цілому. Одним із шляхів підвищення економічної ефекттивності господарств є мінімізація обробітку грунту і раціональне використання добрив. Саме тому нами було досліджено раціональне використання добрив за різних способів обробітків грунту. Дослід включав 4 обробітки грунту: оранка, мінімальний обробіток, прямий осів, щілювання. За кожного із цих обробітків вивчали дію аміачної селітри (AN) і карбамід-аміачної суміші (UAN) на фоні фосфорно-калійних добрив. Ці два фактори досліджувалися у короткоротаційній сівозміні: кукурудза на зерно, соя, пшениия яра. Під кукурудзу на зерно вносили $N_{140} P_{100} K_{100^{\circ}}$ під сою $-N_{60} P_{60} K_{60^{\prime}}$ під пшеницю яру $-N_{100} P_{80} K_{80^{\circ}}$

У результаті було встановлено, що оптимальним обробітком грунту для всіх культур стало щілювання. I кращим азотним добривом виявився КАС для сої і пшениці ярої. У цих варіантах отримано максимальний прибуток: 95,0 \% для сої і 58,1 \% - для пшениці ярої. Для кукурудзи на зерно кращим добривом була аміачна селітра , де прибуток склав 54,7\%.

Ключові слова: аміачна селітра (Naa), КАC, обробіток грунту, сільськогосподарські культури 
А. Быкин, Н. Быкина, Н. Бордюжа, А. Іваныцькая (2019). Экономическая эффективность применения удобрений под сельскохозяйственные культуры при разных способах обработки почвы. PLANT AND SOIL SCIENCE, 10(1): 62-69. https://doi.org/10.31548/agr2019.02.062

Аннотация. В экономических условиях Украины существует конкуренция между производителями продукции растениеводства и она провоцирует развитие их конкурентоспособности на внутреннем и мировом рынках. Это обеспечивает экономическую эффрективность предприятий. Одним из путей повышения экономической эфрфективности для предприятий есть минимизация обработки почвы и рациональное использование удобрений. Именно эти факторы и били нами исследованы.

Действие аммиачной селитры и КАС на фоне фосфорно-калийных удобрений изучали в короткоротационарном севообороте (кукуруза на зерно, соя, пшеница ярая) при вспашке, минимальной обработке, прямом посеве, щелевании. Под кукурузуна зерно вносили $N_{140} P_{100} K_{100}$ под сою $-N_{60} P_{60} K_{60}$ под пшеницу яровую $-N_{100} P_{80} K_{80^{\circ}}$

В результате было установлено, что оптимальной обработкой почвы для всех культур было щелевание. Максимальный доход был 95,0 \% для сои и 58,1 \% - для пшеницы ярой при внесении КАС. Для кукурузы на зерно лучшим удобрением была аммиачная селитра, где прибыль составила $54,7 \%$.

Ключевые слова: аммиачная селитра (Naa), КАC, обработка почвы, сельскохозяйственные культуры. 